E-ISSN : 2549-6581

DOI: 10.21776/ub.JOIM.2021.005.02.3

Artikel Hasil Penelitian

Diterima : 4 Januari 2020

Direview : 14 Juni 2021

Dimuat : Agustus - November 2021

\section{OPEN ACCESS}

Journal of Issues in Midwifer

\title{
Pengaruh Pemberian Air Rebusan Biji Alpukat (Persea americana Mill) Terhadap Pertumbuhan Jamur Candida albicans Secara In Vitro
}

\author{
Nayla Nabilla Tahta Avwina Amir ${ }^{1 *)}$, Sri Winarsih ${ }^{2}$, Bambang Rahardjo ${ }^{3}$ \\ $\left.{ }^{1 *}\right)$ Program Studi S1 Kebidanan, Fakultas Kedokteran, Universitas Brawijaya, \\ Email: naylatahta@gmail.com,Tlp : +62895367377502 \\ ${ }^{2}$ Fakultas Kedokteran, Universitas Brawijaya, Email: wiensri238@gmail.com \\ ${ }^{3}$ RSSA Malang, Email: bar_feto@yahoo.com
}

\begin{abstract}
The most common cause of patalogis leucorrhoea is infection, one of which is Vulvovaginal Candidiasis (VVC) caused by fungus, while $80 \%-90 \%$ is caused by Candida albicans. Approximately $90 \%$ of young women in Indonesia have the potential to experience vaginal discharge because Indonesia is a tropical climate. Alternative treatment for antifungal drugs is needed through the exploration of natural material sources that have the potential as antifungals to deal with this infection safely and easily. The design used in this study was experimental research by in vitro using the dilution method of the tube. Treatment concentrations are 45\%; 40\%; 35\%; 30\%; $25 \%$; $20 \%, 15 \%$ and $0 \%$ with Candida albicans 104 CFU / ml samples from the microbiology laboratory of the medical faculty Brawijaya University and repeated 3 times. The result showed that at all concentrations, growth was still obtained in agar media so that it could be denied that the boiled water of avocado seeds had no effect on the growth of Candida albicans fungal colonies in vitro because there were still fungal colonies on the plates.
\end{abstract}

Keywords: Antifungal, avocado seeds, Candida albicans

\section{ABSTRAK}

Penyebab keputihan patalogis paling sering yaitu infeksi, salah satunya Vulvovaginal Candidiasis (VVC) yang disebabkan oleh jamur, sedangkan $80 \%-90 \%$ disebabkan oleh Candida albicans. Di Indonesia sekitar $90 \%$ remaja putri memiliki potensi terjadi keputihan karena Indonesia adalah daerah dengan iklim tropis. Obat alternative pengganti antijamur sangat diperlukan melalui eksplorasi sumber bahan yang ada di alam yang berpotensi sebagai antijamur untuk menangani infeksi ini secara aman dan mudah. Desain yang digunakan adalah penelitian eksperimental dengan cara in vitro menggunakan metode dilusi tabung. Konsentrasi ekstrak air rebusan biji alpukat yaitu 45\%; 40\%; 35\%; 30\%; 25\%; 20\%, 15\% dan 0\% dengan sampel Candida albicans $104 \mathrm{CFU} / \mathrm{ml}$ dari laboratorium mikrobiologi fakultas 
kedokteran Universitas Brawijaya dan dilakukan pengulangan tiga kali. Dari hasil penelitian didapatkan bahwa pada semua konsentrasi masih didapatkan pertumbuhan di media agar sehingga dapat disimpulkan bahwa air rebusan biji alpukat tidak berpengaruh terhadap pertumbuhan koloni jamur Candida albicans secara in vitro karena masih adanya koloni jamur pada plate.

Kata Kunci: Antijamur, biji alpukat, Candida albicans

*Korespondensi: Nayla Nabilla Tahta Avwina Amir. Surel: naylatahta@gmail.com

\section{PENDAHULUAN}

Infeksi Saluran Reproduksi

(ISR) adalah salah satu masalah kesehatan yang sangat serius yang dialami wanita serta sulit untuk dilakukan diagnosis karena seringkali tidak menimbulkan gejala. Flour albus/keputihan salah satu dari infeksi saluran reproduksi wanita'. Flour albus merupakan penyakit yang hampir setiap wanita pernah mengalaminya, keputihan merupakan permulaan dari kanker serviks yang merupakan pembunuh nomor satu bagi wanita dengan insiden mencapai angka 100/100.000 penduduk pertahun ${ }^{1}$.

$$
\text { Permasalahan ISR di Asia }
$$

yang mengalami keputihan sebanyak 76\%. Di Indonesia sekitar $90 \%$ dari remaja putri memiliki potensi terjadi keputihan dikarenakan negara ini memiliki iklim tropis, sehingga jamur, bakteri dan virus mudah untuk tumbuh ${ }^{2}$. Kasus keputihan atau keputihan di Indonesia semakin meningkat dibuktikan pada hasil penelitian tertera terdapat 52\% wanita mengalami keputihan tahun 2010, kemudian pada tahun 2011 diketahui $60 \%$ wanita mengalami keputihan, selanjutnya wanita di Indonesia pernah mengalami keputihan mencapai $70 \%$ ditahun 2012, sedangkan bulan januari sampai agustus tahun 2013 hampir $55 \%$ wanita di indonesia pernah mengalami keputihan ${ }^{1}$. Penyebab keputihan patalogis paling sering yaitu infeksi, salah satunya Vulvovaginal Candidiasis yang disebabkan oleh jamur, sedangkan 80\%-90\% disebabkan oleh Candida albicans'.

Berbagai macam terapi obat saat ini digunakan untuk pengobatan infeksi penyebab jamur candida. Terapi obat dari golongan polien, golongan imidazole salah satu turunannya adalah Ketokonazol, obat ini merupakan pengobatan standar dari kandidiasis vulvovaginalis dan golongan flusitosin. Akan tetapi beberapa macam obat-obatan yang tersedia untuk mengobati penyakit infeksi karena jamur candida, memiliki mekanisme molekuler yang telah resisten terhadap pertumbuhan jamur Candida albicans ${ }^{3}$. Suatu alternatif obat antijamur sangat diperlukan melalui eksplorasi sumber bahan yang ada di alam yang berpotensi sebagai antijamur. Terdapat banyak penelitian yang menyebutkan tumbuh-tumbuhan sebagai antifungi, seperti yang terkenal di masyarakat antara lain: daun sirih ${ }^{4}$, kunyit ${ }^{5}$, Biji alpukat ${ }^{6}$ dan masih banyak lainnya.

Beberapa penelitian mengenai biji buah dari avocado atau alpukat adalah salah satu buah yang sangat banyak mengandung nutrisi dan vitamin didalamnya. Tetapi biji alpukat selama ini selalu dibuang. Kebanyakan orang mengolah dan mengkonsumsi bagian daging buah dan membuang 
bijinya $^{7}$. Namun ternyata Alpukat mempunyai segudang manfaat dan kandungan, salah satunya adalah mengandung zat aktif saponin ${ }^{8,9}$, $\operatorname{tanin}^{10}$ dan flavonoid $^{9}$. Zat aktif ini digunakan untuk antioksidan, antibakteri dan juga antifungi.

Dengan mekanisme zat aktif yang terdapat dalam biji alpukat, peneliti tertarik untuk meneliti pengaruh air rebusan biji alpukat yang dapat menghambat pertumbuhan jamur Candida albicans secara in vitro. Digunakannya metode rebusan pada penelitian ini guna mengetahui manfaat air rebusan dari hasil merebus biji alpukat yang diharapkan masyarakat dapat mengolah sendiri biji alpukat dengan mudah dirumah tanpa harus mengekstrak dengan bahan lainnya dan dengan biaya yang terjangkau.

Berdasarkan pemikiran diatas perlu dilakukan penelitian mengenai pengaruh air rebusan biji alpukat terhadap jamur Candida albicans sebagai anti jamur.

\section{METODE}

\section{Tempat penelitian dan Waktu Penelitian}

Penelitian dilakukan di Laboratorium Mikrobiologi Fakultas Kedokteran Universitas Brawijaya dan masa penelitian yaitu bulan Februari-April 2020.

\section{Desain penelitian dan Sampel Penelitian}

Desain yang digunakan yaitu penelitian eksperimental. Pengujian antifungi ini dengan cara in vitro, menggunakan metode dilusi tabung untuk mengetahui pengaruh air rebusan biji alpukat sebagai antifungi terhadap jamur Candida albicans. Metode tes dilusi tabung melalui tahap menentukan kadar hambat minimum (KHM) dengan menilai tingkat kekeruhan dalam tabung dan tahap menentukan kadar bunuh minimum (KBM) dengan penggoresan pada SDA (Suboraud Dextrose Agar) $^{11}$.

Sampel ini menggunakan sampel jamur Candida albicans standar yang didapatkan dari Laboratorium Mikrobiologi Universitas Brawijaya Malang. Dilakukan pengulangan perlakuan pada jamur Candida albicans dengan metode dilusi tabung sebanyak 4 (empat) kali.

\section{Alat dan Bahan}

Alat yang dipakai adalah: aluminium foil, bunsen, colony counter, erlenmeyer, Ose, Inkubator, panci, kapas, kompor gas, korek api, tabung steril, mikroskop, spektrofotometer, Mikropipet, mikrotip steril, spidol.

Bahan yang digunakan adalah biji alpukat kering, medium SDA, aquadest steril, $\mathrm{NaCl}$ 0,9\%.

\section{Pembuatan Sediaan Air Rebusan Biji Alpukat}

Biji alpukat kering (simplisia) dilakukan penimbangan sebesar 50 gram untuk menghasilkan konsentrasi awal sediaan $50 \%$, kemudian dimasukkan ke wadah dan diberi aquades steril sebanyak $100 \mathrm{ml}$ dikarenakan biji alpukat yang banyak menyerap air, kemudian direbus selama 15 menit. Kemudian diangkat dan didinginkan. Air kemudian disaring dengan kasa steril ditampung di dalam beaker glass steril dan ditutup, sehingga diperoleh $20 \mathrm{ml}$ air rebusan biji alpukat dengan konsentrasi awal sediaan $50 \%$. 


\section{Pembuatan Suspensi Uji Candida albicans}

Kepadatan sel jamur Candida albicans diukur dahulu dengan alat spektrofotometer (OD 0,1 pada $\lambda=530 \mathrm{~nm}$ ). Nilai OD ini setara dengan konsentrasi $10^{6} \mathrm{CFU} / \mathrm{ml}$ bakteri/ml (Murray et al, 1999). Konsentrasi Jamur Candida albicans $10^{6} \quad \mathrm{CFU} / \mathrm{ml}$ tersebut kemudian diencerkan dengan $\mathrm{NaCl}$ $0,9 \%$ sampai menjadi konsentrasi $10^{4} \mathrm{CFU} / \mathrm{ml}$.

\section{Uji Aktivitas Antifungi}

Disediakan 8 tabung reaksi, untuk perlakuan 45\%, 40\%; 35\%; $30 \%$; 25\%; $20 \%$, $15 \%$ dan kontrol negatif atau $0 \%$.

Tabel 1 Sediaan konsentrasi air rebusan biji alpukat (Persea americana Mill)

\begin{tabular}{|c|c|c|c|}
\hline No & $\begin{array}{c}\text { Konsentrasi } \\
\text { Air Rebusan } \\
\text { Biji Alpukat }\end{array}$ & $\begin{array}{c}\text { Volume } \\
\text { Air } \\
\text { Rebusan } \\
\text { biji } \\
\text { alpukat }\end{array}$ & $\begin{array}{c}\text { Volume } \\
\text { Candida } \\
\text { albicans } \\
10^{4}\end{array}$ \\
\hline 1 & $45 \%$ & $1,8 \mathrm{ml}$ & $0,2 \mathrm{ml}$ \\
\hline 2 & $40 \%$ & $1,6 \mathrm{ml}$ & $0,4 \mathrm{ml}$ \\
\hline 3 & $35 \%$ & $1,4 \mathrm{ml}$ & $0,6 \mathrm{ml}$ \\
\hline 4 & $30 \%$ & $1,2 \mathrm{ml}$ & $0,8 \mathrm{ml}$ \\
\hline 5 & $25 \%$ & $1,0 \mathrm{ml}$ & $1,0 \mathrm{ml}$ \\
\hline 6 & $20 \%$ & $0,8 \mathrm{ml}$ & $1,2 \mathrm{ml}$ \\
\hline 7 & $15 \%$ & $0,6 \mathrm{ml}$ & $1,4 \mathrm{ml}$ \\
\hline 8 & $0 \%$ & $2,0 \mathrm{ml}$ & 0 \\
\hline
\end{tabular}

Hasil statiska Uji One-Way Anova didapatkan nilai $\mathrm{p}=0.000$ bahwa dari data pertumbuhan jumlah koloni tersebut mempunyai perbedaan. Untuk hasil analisis perbedaan tiap perlakuan digunakan uji post hoc tuckey. Hasil uji didapatkan bahwa tidak terdapat perbedaan pada konsentrasi $20 \%$ dengan $25 \%$ dan $30 \%$ dengan $35 \%$ sehingga menunjukkan konsentrasi mempunyai kemampuan sama terhadap pertumbuhan koloni
Candida albicans. Dari hasil uji Korelasi didapatkan nilai $r=-.993$ menunjukkan adanya korelasi yang kuat dengan koefisien korelasi yang mendekati 1 antara konsentrasi dan jumlah koloni jamur. Tanda minus () menandakan bahwa terdapat korelasi yang berlawanan atau berbanding terbalik antar variabel sehingga dapat diartikan semakin besar konsentrasi yang digunakan maka semakin sedikit pertumbuhan koloni.

\section{HASIL PENELITIAN}

Penelitian daya hambat air rebusan biji alpukat (Persea americana) terhadap jamur Candida albicans penyebab kandidiasis vulvovaginalis didapatkan hasil pada tabel berikut.

Tabel 2 Data Jumlah koloni hasil streaking pengaruh pemberian rebusan biji alpukat (Persea americana Mill) terhadap pertumbuhan jamur Candida albicans secara in vitro

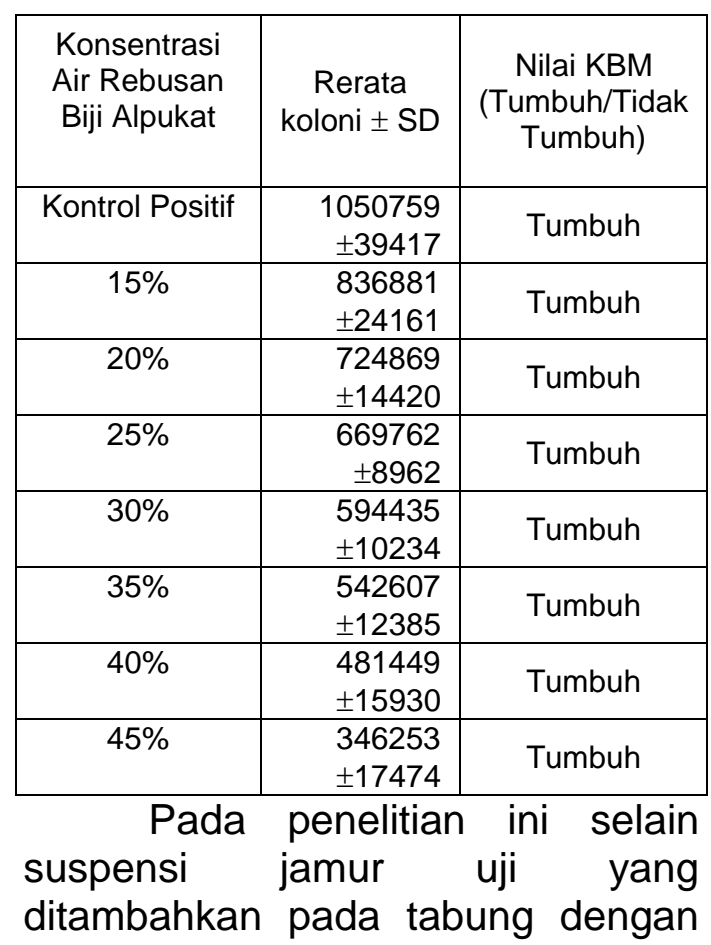


perlakuan konsentrasi air rebusan biji alpukat, dilakukan streaking (penggoresan) penanaman pada medium agar untuk mengetahui jumlah koloni.

Pada semua konsentrasi masih didapatkan pertumbuhan di media agar berdasarkan hasil uji terdapat tiga pengulangan diuji. Pertumbuhan koloni jamur Candida albicans pada konsentrasi $0 \%, 15 \%$, $20 \%, 25 \%, 30 \%$ dan $35 \%$ tidak terjadi perubahan koloni atau tidak terjadi penurunan jumlah koloni (lihat gambar 1). Sedangkan pada konsentrasi $35 \%-40 \%$ terdapat sedikit penurunan yang ditunjukkan pada kerenggangan koloni yang terlihat pada plate (lihat gambar 2). Maka jumlah pertumbuhan koloni jamur Candida albicans konsentrasi biji alpukat $15 \%$ sampai $35 \%$ walaupun terdapat penurunan akan tetapi koloni masih terlihat sama antar konsentrasi. Sedangkan pada isolat dengan konsentrasi 15\%-40\% terlihat kecenderungan koloni makin menurun. Dengan demikan, air rebusan biji alpukat sangat lemah dalam mempengaruhi pertumbuhan jamur Candida albicans (lihat gambar 3).

\section{PEMBAHASAN}

Dilakukan Penelitian ini untuk mengetahui pengaruh air rebusan biji alpukat sebagai antifungi terhadap jamur Candida albicans secara in vitro. Setelah diberi perlakuan dengan menggunakan metode dilusi tabung, diperoleh bahwa untuk mengetahui kekeruhan tidak dapat dilakukan dikarenakan sediaan berwarna gelap. Sehingga dilakukan streaking atau penanaman preparat dilusi tabung pada SDA untuk mengetahui jumlah koloni. Pada penelitian ini diperoleh semua konsentrasi masih terdapat petumbuhan koloni pada SDA setelah diinkubasikan selama 18-24 jam pada suhu $37^{\circ} \mathrm{C}$.

Pengujian daya hambat yang telah dilakukan sudah dengan cara aseptis akan tetapi tetap menunjukkan bahwa air rebusan biji alpukat tidak mampu menghambat pertumbuhan jamur Candida albicans secara signifikan walaupun terdapat penurunan terlihat dari pertumbuhan koloni jamur Candida albicans yang semakin menurun. Penurunan ini dapat disebabkan oleh beberapa faktor yakni kandungan zat aktif yang didalamnya dan pengaruh rebusan terhadap zat aktif yang ada di dalam biji alpukat. 


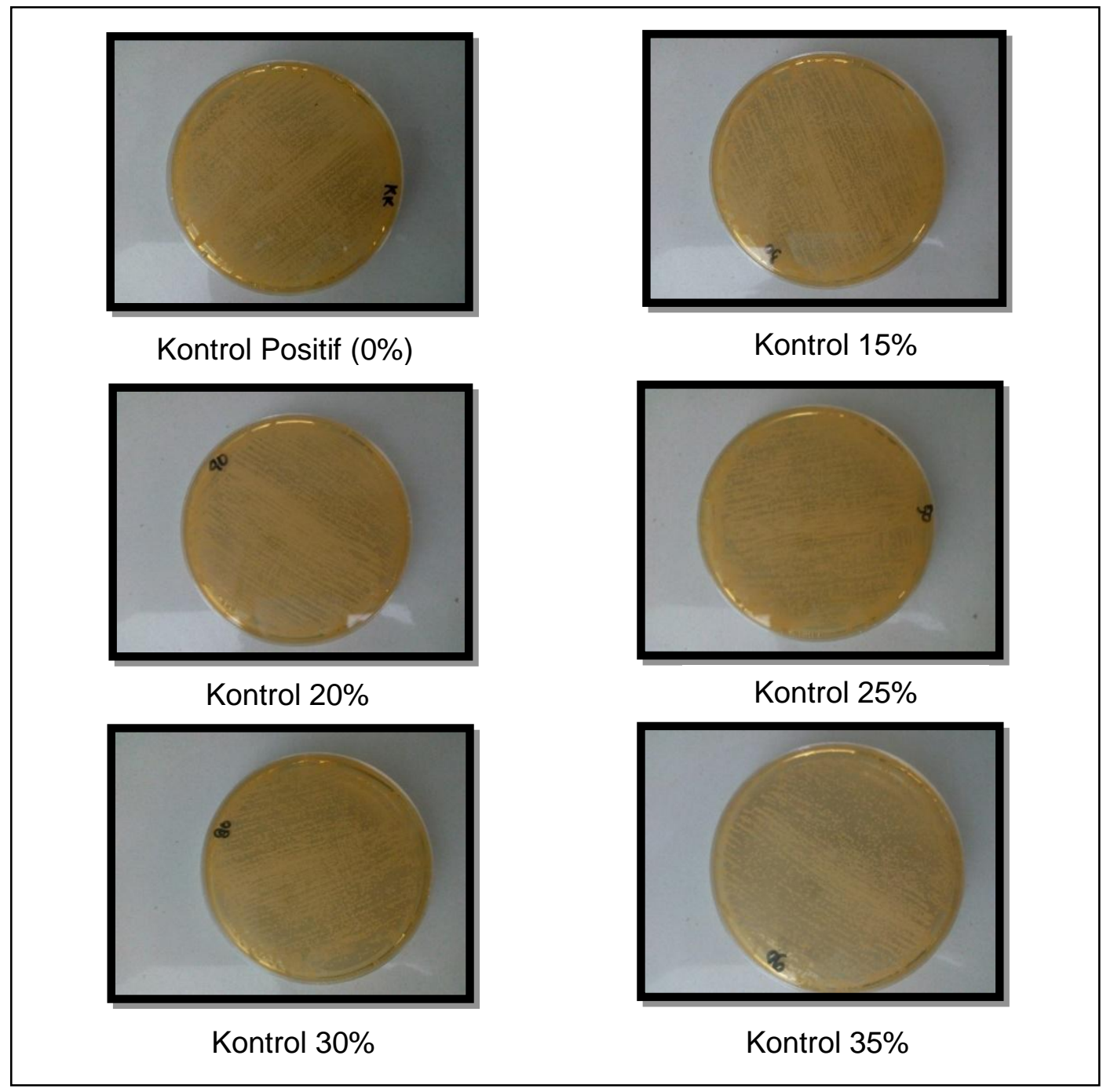

Gambar 1 Koloni Candida albicans dengan konsentrasi 0\%, 15\%, $20 \%, 25 \%, 30 \%$ dan $35 \%$ 


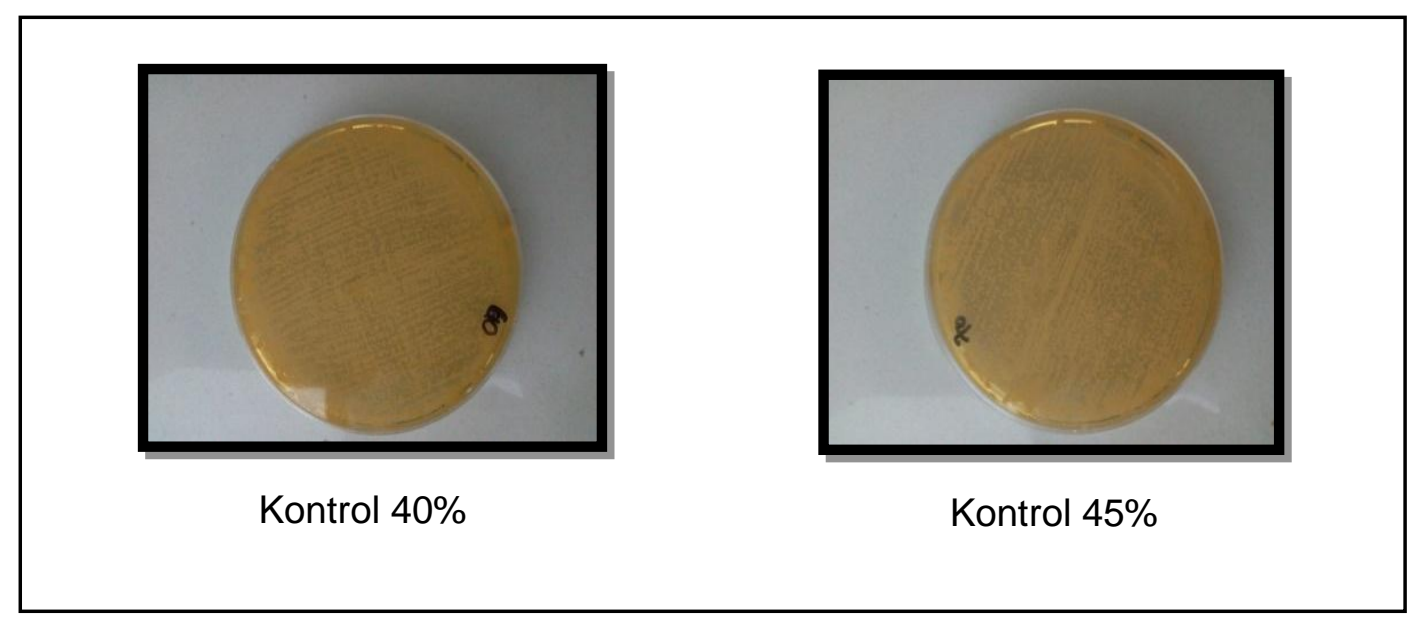

Gambar 2 Koloni Candida albicans dengan konsentrasi $40 \%$ dan $45 \%$

Dalam penelitian yang $0,1804 \%$. Senyawa fenol pada biji dilakukan Rivai, $\mathrm{dkk}^{12}$ disebutkan alpukat merupakan satu golongan

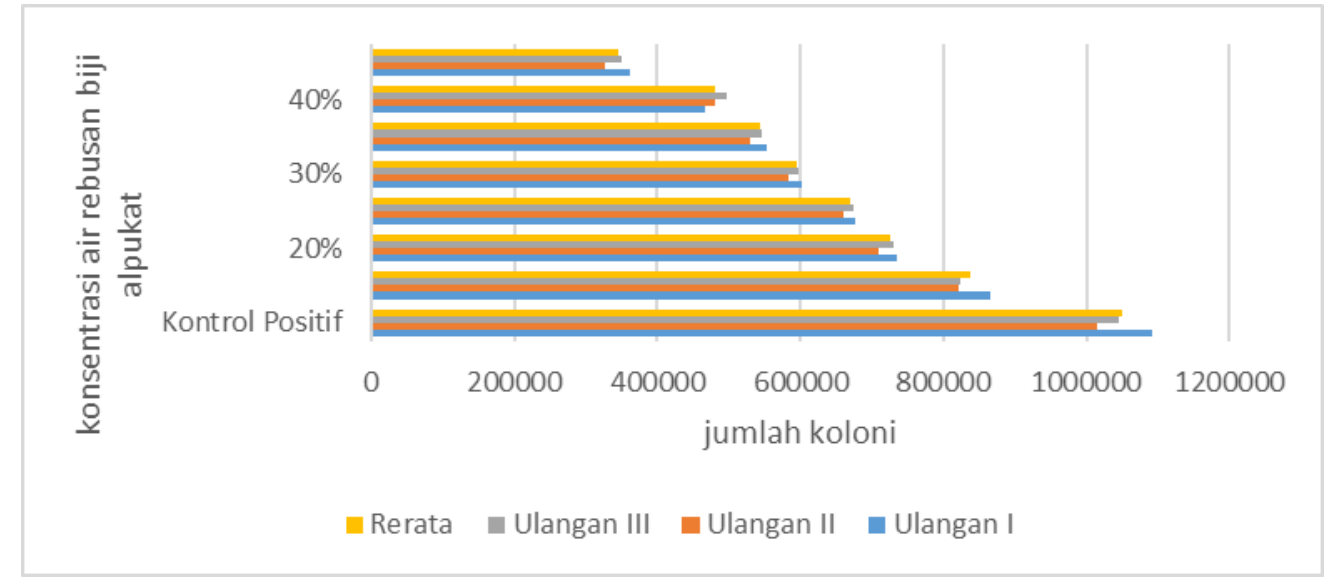

\section{Gambar 3 Grafik jumlah koloni berdasarkan perlakuan air rebusan biji alpukat}

bahwa menurut skrining fitokimia dari biji alpukat mengandung zat aktif diantaranya: saponin, tannin, alkaloid, triterpenoid, dan juga flavonoid dengan pelarut eter akan tetapi ketika pengujian dengan menggunakan bahan pelarut air (dengan metode rebusan) dalam air rebusan biji alpukat mengandung senyawa aktif fenol dan tannin. Disebutkan dalam penelitian Rivai, $(2019)^{13}$ kadar yang tekandung dalam biji alpukat dengan pelarut air yang telah direbus diatas penangas air yaitu fenol 0,0494\% dan tanin dengan flavonoid, senyawa memiliki fungsi antifungi yang menghambat pertumbuhan jamur Candida albicans menghambat morfogenetik dan menghambat pembentukan biofilm karena pengaturan regulasi gen DPP3. Gen DPP3 diketahui melakukan peran penting dalam sintesis farnesol karena mengkode enzim yang mengubah farnesyl pyrophosphate menjadi farnesol ${ }^{14}$. Senyawa fenol dapat pula berikatan dengan bagian yang menyusun membran sel jamur yaitu ergosterol sehingga pada membran sel 
terbentuk pori. Hal ini menyebabkan kematian sel jamur kerena komponen sel jamur keluar dari sel 15.

Senyawa fenol mempunyai sifat larut dalam air dengan mudah, cepat dalam membentuk kompleks dengan protein dan juga reaktif dengan oksidasi pada enzim . Kadar fenol semakin meningkat bila suhu yang digunakan semakin tinggi pada ekstraksi maka semakin lama masa waktu yang digunakan maka akan banyak fenol yang diserap. Namun fenol $(\mathrm{C} 6 \mathrm{H} 5 \mathrm{OH})$ hanya sedikit zat yang larut didalam air (9 $\mathrm{g} / 100 \mathrm{~g}$ air) dikarenakan bobot dari molekul air sendiri adalah rendah dan turun sedangkan titik beku molal dari fenol yaitu 7,5 yang termasuk tinggi ${ }^{16}$.

Kegunaan tanin pada biji alpukat sebagai antifungi karena zat tanin mempunyai sifat lipofilik menyebabkan tanin mudah bersatu dengan dinding sel sehingga terjadi kerusakan pada dinding sel. Selain itu, senyawa ini menghambat sintesis salah satu komponen dinding sel jamur yaitu kitin ${ }^{17}$. Tanin juga bersifat koloid dan memiliki gugus phenol, dengan ini senyawa ketika didalam air tanin bersifat asam lemah dan bersifat koloid. Dalam pelarut organik (aseton, etanol, methanol dan lain-lain) tanin dengan mudah dapat larut dan semua macam senyawa tanin dapat larut dalam pelarut air, bertambah besar kelarutannya apabila dilarutkan dalam air panas. Terurainya senyawa tanin menjadi pyrocatechol, phloroglucinol dan pyrogallol, bila senyawa dipanaskan hingga suhu $98,89^{\circ} \mathrm{C}$ $101,67^{\circ} \mathrm{C}^{18}$.

Berdasarkan Idris $(2009)^{19}$ yang telah melakukan penelitian di
Nigeria menghasilkan bahwa aktivitas ekstrak biji alpukat dengan pelarut etil asetat, kloroform dan metanol dapat menghambat pertumbuhan jamur berdasarkan zona hambatan pertumbuhan, dibandingkan dengan antibiotik atau bahkan melampaui antibiotik standar yaitu streptomisin, juga melampaui obat kandidiasis yang umum dipakai yaitu Ketokonazol 2\% berdasarkan zona hambat yang telah diteliti ${ }^{20}$.

Dalam penelitian pengaruh air rebusan biji alpukat terhadap pertumbuhan Candida albicans secara In Vitro yang telah dilakukan dapat dilihat adanya penurunan akan tetapi sangat sedikit dan masih terdapat adanya jamur yang tumbuh dalam plate. Sehingga herbal air rebusan biji alpukat tidak efektif untuk digunakan sebagai obat alternatif kandidiasis vulvovaginalis, akan tetapi biji alpukat ini dapat di olah untuk dijadikan antifungi dengan mengektraksi dengan metode lain untuk mengambil manfaat dari biji alpukat ini atau dapat dengan menguji dengan konsentrasi air rebusan $>45 \%$ melihat dari konsentrasi tersebut terlihat adanya penurunan yang baik dari pada konsentrasi yang lain, karena pemanfaatan dari biji alpukat ini masih menjadi potensi yang sangat menguntungkan dibalik pemanfaatan buah itu sendiri.

Pada penelitian ini mengalami beberapa keterbatasan dan juga kendala, yang pertama dari metode yang dipakai seharusnya dapat dilakukan dengan metode uji lain, namun dikarenakan air rebusan dari biji alpukat sangat keruh sehingga tidak dapat diuji untuk KHM disebabkan sediaan tidak homogen dengan jamur uji. 
Kedua, penelitian ini tidak dapat maksimal dan tidak dapat menggunakan pengujian yang lain karena ada peraturan yang membatasi terkait pandemi Covid19 yang sedang terjadi.

\section{KESIMPULAN}

Dari hasil penelitian dapat disimpulkan bahwa air rebusan biji alpukat memiliki daya hambat yang lemah terhadap pertumbuhan jamur Candida albicans secara in vitro karena masih ada nya pertumbuhan jamur pada plate. Sehingga pengaruh air rebusan biji alpukat terhadap pertumbuhan jamur Candida albicans tidak signifikan. Hasil menunjukkan adanya penurunan pertumbuhan pada koloni jamur akan tetapi masih terdapat koloni jamur yang tumbuh.

\section{SARAN}

Setelah adanya hasil penelitian ini, peneliti selanjutnya disarankan dengan menggunakan metode ekstraksi lain supaya zat aktif untuk antifungi dapat diambil secara maksimal dan dapat dimanfaatkan sebagai bahan alternatif pengganti obat dikarenakan potensi dalam pemanfaatan dari biji alpukat ini masih perlu digali lagi.

\section{DAFTAR PUSTAKA}

1. Darma, M., Sartiah , Y., Andi Ff. Hubungan Pengetahuan, Vulva Hygiene, Stres , Dan Pola Makan Dengan Kejadian Infeksi Flour Albus (Keputihan) Pada Remaja Siswi Sma Negeri 6 Kendari 2017. J Ilm Mhs Kesehat Masy. 2017;2(6):1-9.

2. Sa U, Widyasih $\mathrm{H}$, Kebidanan Psd, Vokasi S, Mada Ug. Personal Hygiene Habits Dan
Kejadian Flour Albus Patologis Pada Santriwati Pp AlMunawwir , Yogyakarta Santriwati Of Pp Al-Munawwir, Yogyakarta. J Mkmi. 2018;14(1):36-43.

3. Bindusari, A., Suyoso S. Bindusari A, Suyoso S. Terapi Kandidiasis Vulvovaginalis. Berkala IImu Penyakit Kulit Dan Kelamin Fakultas Kedokteran Universitas Airlangga. 2001;Bindusari:147-55.

4. Rahmah N, Rahman Ak. Uji Fungistatik Ekstrak Daun Sirih (Piper betle L) Terhadap Candida albicans. Bioscientiae. 2010;

5. Pulungan Ass. Aktivitas Antijamur Ekstrak Etanol Daun Kunyit (Curcuma longa Linn.) Terhadap Jamur Candida albicans. Biolink (Jurnal Biol Lingkungan, Ind Kesehatan). 2017;

6. Kusumo Pd, Nae Ak. Aktivitas Antijamur Ekstrak Biji Alpukat (Persea americana Mill.) Terhadap Pertumbuhan Candida albicans. Bunga Rampai Saintifika Fk Uki. 2018;

7. Faza A. Sering Dibuang, Ternyata Kulit Biji Alpukat Lebih Menyehatkan [Internet]. 2017. Available From: Https:/Www.PikiranRakyat.Com/HidupGaya/2017/08/23/SeringDibuang-Ternyata-Kulit-BijiAlpukat-Lebih-Menyehatkan408006

8. Febriani T. Uji Daya Antifungi Jus Buah Pare (Momordica charantia L) Terhadap Daya Hambat Pertumbuhan Candida 
albicans Secara In Vitro. J Chem Inf Model. 2018;

9. Anna K Jager Shf. Correlation Between Plant Secondary Metabolites And Their Antifungal Mechanisms-A Review. Med Aromat Plants. 2014;

10. Ismarani. Potensi Senyawa Tannin Dalam Menunjang Produksi Ramah Lingkungan. J Agribisnis Dan Pengemb Wil. 2012;

11. Dzen, S.M., dkk. Bakteriologi Medik., Tim Mikrobiologi Fakultas Kedokteran Universitas Brawijaya, Malang. 2013

12. Rivai H, Putri Yt, Rusdi R. Qualitative And Quantitative Analysis of The Chemical Content Of Hexane, Acetone , Ethanol And Water Extract From Avocado Seeds ( Persea americana Mill .) Experimental Section / Material And Methods. Sch Int J Tradit Andcomplementary Med. 2019;2(3):25-31.

13. Marlinda M, Sangi Ms, Wuntu Ad. Analisis Senyawa Metabolit Sekunder Dan Uji Toksisitas Ekstrak Etanol Biji Buah Alpukat (Persea americana Mill.). J Mipa. 2012;

14. Ansari Ma, Anurag A, Fatima Z, Hameed S. Natural Phenolic Compounds: A Potential Antifungal Agent. In: Microbial Pathogens And Strategies For Combating Them: Science, Technology And Education. 2013.
15. Wahyuni S, Mukarlina, Yanti Ah. Aktivitas Antifungi Ekstrak Metanol Daun Buas-Buas Premna serratifolia ) Terhadap Jamur Diplodia sp. Pada Jeruk Siam ( Citrus nobilis Var. Microcarpa ). Protobiont. 2014;

16. Rondang Tambun D. Fenol Dari Lengkuas Merah Influence Of Particle Size, Time And Temperature To Extract Phenol. Tek Kim Usu, Vol 5, No 4 (Desember 2016) Pengaruh. 2016;

17. Raniyanti Rieska Alfiah, Siti Khotimah Mt. Efektivitas Ekstrak Metanol Daun Sembung Rambat ( Mikania Micrantha Kunth ) Terhadap Pertumbuhan Jamur Candida albicans. J Protobiont. 2015;

18. Irianty Rsri, Yenti Sr. Pengaruh Perbandingan Pelarut Etanol-Air Terhadap Kadar Tanin Pada Sokletasi Daun Gambir ( Uncaria gambir Roxb ) [ Effect Of Ethanol-Water Solvent Ratio On Levels Of Tannins In Leaves Gambier Socletation ]. 2014;13(1):1-7.

19. Idris S, Ndukwe Gi, Gimba Ce. Preliminary Phytochemical Screening And Antimicrobial Activity Of Seed Extracts Of Persea americana ( Avocado Pear ). 2009;2(1):173-6.

20. Siddik Mb, Budiarti Ly, Edyson E. Perbandingan Efektivitas Antifungi Antara Ekstrak Metanol Kulit Batang Kasturi Dengan Ketokonazol 2\% Terhadap Candida albicans In Vitro. Berk Kedokt. 2016; 